\title{
Effectiveness and tolerability of a fixed-dose combination of olmesartan and amlodipine in clinical practice
}

This article was published in the following Dove Press journal:

Vascular Health and Risk Management

25 August 2010

Number of times this article has been viewed

\author{
Peter Bramlage' \\ Wolf-Peter Wolf ${ }^{2}$ \\ Thomas Stuhr ${ }^{2}$ \\ Eva-Maria Fronk ${ }^{3}$ \\ Wolfhard Erdlenbruch ${ }^{2}$ \\ Reinhard Ketelhut ${ }^{4}$ \\ Roland E Schmieder ${ }^{5}$ \\ IInstitute for Cardiovascular \\ Pharmacology and Epidemiology, \\ Mahlow; ${ }^{2}$ Daiichi Sankyo Deutschland \\ GmbH, Munich, Germany; ${ }^{3}$ Daiichi \\ Sankyo Europe GmbH, Munich, \\ Germany; ${ }^{4}$ Department of Sports \\ Medicine, Universitätsklinikum Berlin; \\ ${ }^{5}$ Department of Nephrology and \\ Hypertension, University Hospital of \\ Erlangen, Germany
}

Objectives: To assess the efficacy and tolerability of a fixed-dose combination of olmesartan and amlodipine in an unselected population of patients in primary care and to compare the results with recent randomized controlled trial evidence.

Methods: A multicenter, noninterventional, noncontrolled observational study with 8241 hypertensive patients seen by 2187 physicians in daily practice. Blood pressure (BP) reduction, comorbid disease, pharmacotherapy, and tolerability were documented over a 12-18-week observational period.

Results: Patients had a mean age of $62.8 \pm 11.8$ years $(48.1 \%$ female), and $74.8 \%$ had at least one comorbid risk factor or condition. In total, $51.3 \%$ received olmesartan-amlodipine $20 / 5 \mathrm{mg}, 30.6 \%$ received $40 / 5 \mathrm{mg}$, and $17.9 \%$ received $40 / 10 \mathrm{mg}$ at baseline, mostly because of lack of efficacy on prior antihypertensive therapy (73.8\%). BP at baseline was $161.8 \pm 16.6 / 93.6 \pm 10.2 \mathrm{mmHg}(39.8 \%$ had Grade 2 hypertension), and the observed BP reduction was $-29.0 \pm 17.1 /-13.5 \pm 10.9 \mathrm{mmHg}(P<0.0001)$, with a significant correlation between BP at baseline and BP reduction (Spearman's Rho -0.811 for systolic BP and -0.759 for diastolic BP). BP reduction appeared to be dependent on dose and prior antihypertensive therapy, but not on age, gender, body mass index, duration of hypertension, or the presence of diabetes. At the final visit, $69.4 \%$ (4.3\% at baseline) were controlled ( $<140 / 90 \mathrm{mmHg}$ ). Adverse drug reactions were observed in $2.76 \%$ of the study population; $94.25 \%$ of these adverse drug reactions were judged as nonserious events, and $31.5 \%$ of all adverse drug reactions reported were peripheral edema.

Conclusion: The fixed-dose olmesartan-amlodipine combination was effective and well tolerated in an unselected population of patients in primary care practice. These results confirm prior randomized controlled trial evidence.

Keywords: blood pressure, cardiovascular risk, antihypertensive treatment, observation

\section{Introduction}

The combination of two antihypertensive drugs is recommended by the European Society of Hypertension (ESH)/European Society of Cardiology (ESC) $)^{1,2}$ in patients with blood pressure (BP) not adequately controlled with antihypertensive monotherapy or as first-line therapy in patients at high risk. Blockers of the renin-angiotensin system, being the foundation of antihypertensive therapy in $>50 \%$ of patients, are recommended to be combined with either thiazide diuretics (hydrochlorothiazide) or calcium channel blockers. Within this context, fixed-dose combinations offer the advantage of easy once-daily dosing which has been shown to improve patient compliance. While there was a preference for thiazide-type diuretics in older recommendations, recent data from the ACCOMPLISH (Avoiding Cardiovascular Events in Combination Therapy 
in Patients Living with Systolic Hypertension) study ${ }^{3}$ have resulted in a shift of this preference. ${ }^{2}$ In ACCOMPLISH, a fixed combination of an angiotensin-converting enzyme (ACE) inhibitor with hydrochlorothiazide was compared with a respective combination incorporating amlodipine, resulting in a significant reduction of cardiovascular morbidity and mortality with the amlodipine combination.

In response to a rising demand for highly effective and tolerable fixed-dose combinations with amlodipine, a combination of olmesartan-amlodipine was developed that was able to reduce BP by $-30.1 /-19.0 \mathrm{mmHg}$ in doses up to $40 / 10 \mathrm{mg}$ in a recent study. ${ }^{4}$ Almost maximal BP reduction was achieved as early as four weeks after treatment initiation and was sustained throughout the eight-week study period. Tolerability was good, with a reduction of incidence of edema, known to be increased with amlodipine monotherapy at high doses. Fixed-dose combinations of antihypertensive drugs improve patient compliance which, in turn, is associated with a reduction in hospitalization and cardiovascular events. ${ }^{5,6}$

These results prompted us to question whether the efficacy and safety results seen in this double-blind randomized clinical trial would be preserved in an open-label, noninterventional, observational study in primary care. This comparison is of particular importance because patients with unusual characteristics (eg, very old/young, very obese/slim, those with abundant concomitant medication) are usually excluded from randomized clinical trials, but are not infrequently encountered in primary care practice.

\section{Patients and methods}

SERVE (DE-SEV-02-08-DE) was a noninterventional, noncontrolled, prospective study in primary care practice in Germany. It was part of a European project including 15,000 patients. Participating practices were sampled at random from specialists in general medicine, internal medicine, cardiology, and practitioners from all regions defined by the Institute of Medical Statistics. The study was conducted according to local laws and regulations ( $\$ 67$ (6) Arzneimittelgesetz, AMG) and the FSA Code (Freiwillige Selbstkontrolle für die Arzneimittelindustrie e.V.), and was duly notified to the federal authorities (Bundesinstitut für Arzneimittel und Medizinprodukte, BfArM) and the federal panel doctors' association (Kassenärztliche Bundesvereinigung, KBV). Ethics committee approval and written patient informed consent were obtained.

\section{Patients}

Patients showing primary arterial hypertension and in whom previous pharmacotherapy did not reach target BP recommended by the ESH were identified. Beyond these criteria, physicians were free to select patients within the scope of drug licensing, ie, no other inclusion and exclusion criteria were defined. They were also allowed to adjust the dosage of the drug and of any concomitant medication throughout the duration of the study according to patients' needs.

\section{Recording of data}

At the enrolment visit, demographic data and data relating to the presence of hypertension (BP, heart rate, target $\mathrm{BP}$ achievement, and duration of hypertension) were obtained. Patient history including further concomitant cardiovascular risk factors and disease (metabolic syndrome, diabetes mellitus, stable angina pectoris, left ventricular hypertrophy, myocardial infarction, stroke/transitory ischemic attack, peripheral arterial disease, reduction of kidney or liver function, and smoking) was documented, along with disease duration. With respect to pharmacotherapy, previous/ concomitant antihypertensive therapy and concomitant non antihypertensive medication were recorded. Finally, the reason for switching to the fixed combination of olmesartanamlodipine was documented.

At the optional checkup visits at 4-6 and 8-12 weeks and the final visit at 12-18 weeks, adverse events, changes in BP, target BP achievement, and physician assessment of patient compliance, effectiveness, and tolerability (very good, good, satisfactory, insufficient) were obtained.

Physicians were asked to document patients who were being treated with olmesartan-amlodipine $(20 / 5 \mathrm{mg}$, $40 / 5 \mathrm{mg}, 40 / 10 \mathrm{mg}$ ) because of inadequately controlled primary arterial hypertension. The documentation forms were recorded by Christine Franzen Consulting, a Clinical Research Organization in Stolberg, Germany. Data were examined for their plausibility in all documentation forms. Five percent of the participating physicians underwent monitoring of their documentation by fax. The patients were recorded in pseudonymized form, ie, only the age and gender of the patient were recorded, and all data collected during the observation period were treated confidentially. Data were electronically stored in accordance with data protection provisions. An honorarium for the documentation of eligible patients was paid in accordance with the official scale of physicians' fees (Gebührenordnung für Ärzte [GOÄ]).

\section{Adverse drug reactions}

Adverse drug reactions were explicitly asked about at each follow-up visit and recorded in detail (eg, nature, date, 
duration, result, and causal relationship with therapy). All physicians were asked to report serious adverse events to the pharmaceutical manufacturer immediately, which in turn notified the BfArM in accordance with legal requirements.

\section{Statistical analysis}

The statistical analysis was descriptively conducted, exploratively assessed, and then produced in tabular and graphic form. For categoric data, absolute and relative frequencies and, for continuous variables, the average and standard deviation were calculated. SAS software (v. 9.2 SAS Institute, Cary, NC) was used for the statistical analyses. The Spearman's Rho was used for rank correlations (relationship of initial BP to reduction in BP). In order to be able to record rare adverse drug reactions, the number of cases was set at 8000 patients, which allowed adverse drug reactions up to an incidence of $0.1 \%$ to be recorded with a probability of almost $100 \%$ and adverse drug reactions with an incidence of $0.01 \%$ and a probability of $55.1 \%$.

\section{Results}

\section{Patient characteristics}

A total of 8241 patients were identified by 2187 physicians between January and December 2009, of whom 8237 had received an olmesartan-amlodipine fixed combination (safety population). Patients had a mean age of $62.8 \pm 11.8$ years (48.1\% female). All but one patient had arterial hypertension (99.99\%), and $47.5 \%$ for more than five years. See Table 1 for further details of patient characteristics. A total of $74.8 \%$ of patients had at least one cardiovascular risk factor or had comorbid cardiovascular disease (mean number $1.9 \pm 2.3$, Figure 1), with diabetes mellitus (33.1\%), metabolic syndrome $(30.0 \%)$, and smoking $(24.9 \%)$ being the most frequent.

Table I Characteristics of patient safety population

\begin{tabular}{llll}
\hline & Data available & $\mathbf{n}$ & Value \\
\hline Age (mean \pm SD, years) & 8237 & & $62.8 \pm 1 \mathrm{I} .8$ \\
Age $\geq 65$ years & 8237 & $384 \mathrm{I}$ & 46.6 \\
Female (\%) & 8237 & 3966 & 48.1 \\
BMI (mean \pm SD; kg/m²) & 8157 & & $29.0 \pm 4.7$ \\
Obesity (\%) & 8157 & 2835 & 34.8 \\
Waist circumference & & & \\
Men $(\% \geq 102 \mathrm{~cm})$ & 3570 & 2119 & 59.4 \\
Women $(\% \geq 88 \mathrm{~cm})$ & 3242 & 2567 & 79.2 \\
Hypertension $(\%)$ & 8237 & 8236 & 99.9 \\
$>5$ years $(\%)$ & 8009 & $380 \mathrm{I}$ & 47.5 \\
\hline
\end{tabular}

Abbreviations: SD, standard deviation; BMI, body mass index.
Table 2 Antihypertensive therapy (safety population; multiple answers possible)

\begin{tabular}{|c|c|c|c|c|c|}
\hline & \multirow[t]{2}{*}{$\begin{array}{l}\text { Data } \\
\text { available }\end{array}$} & \multicolumn{2}{|c|}{ Baseline } & \multicolumn{2}{|c|}{$\begin{array}{l}\text { After } \\
\text { initiation }\end{array}$} \\
\hline & & $\mathbf{n}$ & $\%$ & $\mathbf{n}$ & $\%$ \\
\hline Beta-blockers & 8237 & 3431 & 41.7 & 2463 & 29.9 \\
\hline Diuretics & 8237 & 2561 & $31.1 * *$ & $166 \mid$ & 20.2 \\
\hline ACE inhibitors & 8237 & 3567 & 43.3 & 534 & 6.5 \\
\hline $\begin{array}{l}\text { Calcium channel } \\
\text { blockers }\end{array}$ & 8237 & 3314 & $40.2^{* *}$ & 511 & 6.2 \\
\hline Amlodipine & 8237 & 2360 & 28.7 & 343 & 4.2 \\
\hline $\begin{array}{l}\text { Angiotensin } \\
\text { receptor blockers }\end{array}$ & 8237 & 3155 & 38.3 & 514 & 6.2 \\
\hline Olmesartan & 8237 & 1288 & 15.6 & 277 & 3.4 \\
\hline Others* & 8237 & 1286 & 15.6 & 922 & 11.2 \\
\hline $\begin{array}{l}\text { Olmesartan- } \\
\text { amlodipine 20/5 }\end{array}$ & 8237 & n.a. & n.a. & 4232 & 51.3 \\
\hline $\begin{array}{l}\text { Olmesartan- } \\
\text { amlodipine 40/5 }\end{array}$ & 8237 & n.a. & n.a. & 2526 & 30.6 \\
\hline $\begin{array}{l}\text { Olmesartan- } \\
\text { amlodipine } 40 / 10\end{array}$ & 8237 & n.a. & n.a. & 1479 & 17.9 \\
\hline
\end{tabular}

Notes: ${ }^{*}$ Central and peripheral acting antiadrenergic drugs/alpha-blockers/vasodilators/ others; ** 1935 patients received fixed-dose combinations of renin angiotensin system blocking agents with either diuretics or calcium channel blockers.

Abbreviations: ACE, angiotensin-converting enzyme; n.a., not applicable.

\section{Antihypertensive treatment at baseline and during follow-up}

In total, 7511/8235 (91.2\%) of patients had received any prior antihypertensive therapy. An olmesartan-amlodipine fixeddose combination was frequently introduced in preference to ACE inhibitors, calcium channel blockers, and angiotensin receptor blockers (Table 2). After initiation, 51.3\% received olmesartan-amlodipine $20 / 5 \mathrm{mg}, 30.6 \%$ received $40 / 5 \mathrm{mg}$, and $17.9 \%$ received $40 / 10 \mathrm{mg}$. Most patients (73.8\%) were switched because of lack of efficacy and $17.3 \%$ because of lack of tolerability on prior therapy, $14.2 \%$ because of insufficient compliance, and $17.4 \%$ were switched from a free combination to a fixed combination of both agents (13.8\% guideline recommendation, $2.6 \%$ missing; multiple answers possible).

The mean duration of exposure was $114.1 \pm 34.5$ days (median 110 [interquartile range 93-128]). Patient compliance was regarded by the physicians to be very good in $66.7 \%$ or good in $28.0 \%$ (total of $94.7 \%$ ), but some patients were switched by the treating physicians between dose combinations (Table 3). In total, $75.1 \%$ received their initial fixed-dose combination until study end, $24.9 \%$ being either up- or downtitrated.

\section{$\mathrm{BP}$ at baseline and during follow-up}

Mean BP at baseline was 161.8 $\pm 16.6 / 93.6 \pm 10.2 \mathrm{mmHg}$ (pulse pressure $68.2 \pm 14.7$ ), the majority being classified to 


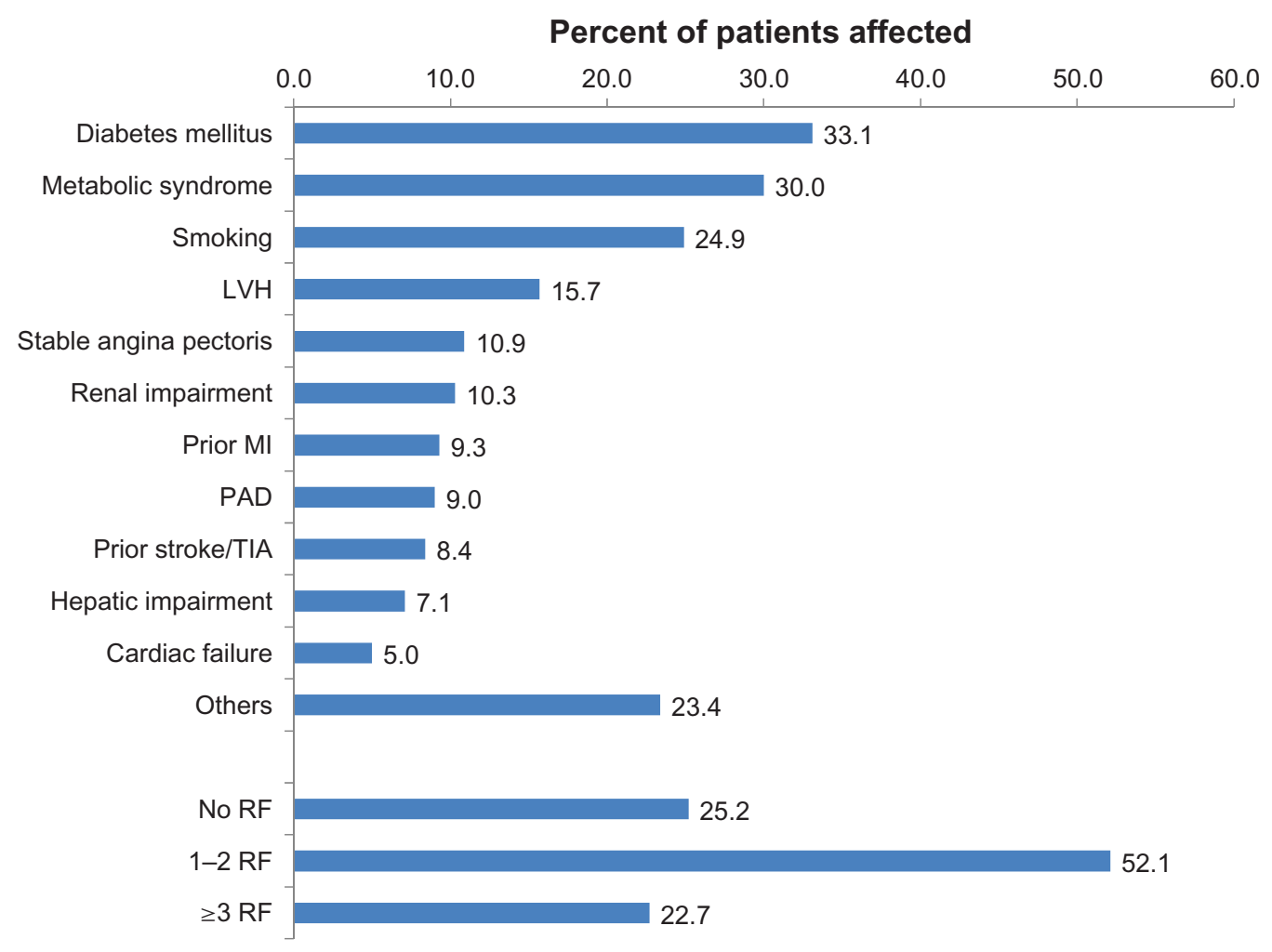

Figure I Comorbid cardiovascular risk factors and disease.

Abbreviations: LVH, left ventricular hypertrophy; MI, myocardial infarction; PAD, peripheral arterial disease; TIA, transient ischemic attack; RF, risk factors.

have ESH/ESC Grade 2 hypertension (39.8\%); 18.3\% and $18.6 \%$ had Grade 1 or Grade 3 hypertension, respectively, and $19.1 \%$ had isolated systolic hypertension. There was an overall mean BP reduction of $29.0 \pm 17.1 / 13.5 \pm 10.9 \mathrm{mmHg}$ $(P<0.0001$ versus baseline; pulse pressure $15.7 \pm 15.0$, $P<0.0001$ versus baseline), that increased dependent on initial BP classification (Figure 2). BP reduction was most pronounced in patients with Grade 3 hypertension ( $-48.3 \pm$ $16.9 /-22.6 \pm 11.4 \mathrm{mmHg}, P<0.0001$ versus baseline). Accordingly, there was a clear correlation between systolic BP reduction and systolic BP at baseline (Spearman's Rho-0.811), diastolic BP reduction and diastolic BP at baseline (Spearman's
Rho -0.759), and pulse pressure reduction and pulse pressure at baseline (Spearman's Rho -0.804).

$\mathrm{BP}$ reduction at the final visit was also dependent on the dose employed (Table 4). Using olmesartanamlodipine $20 / 5 \mathrm{mg}$, a mean $\mathrm{BP}$ reduction of $-27.6 \pm 16.3 \mathrm{mmHg} /-13.2 \pm 10.6 \mathrm{mmHg}$ was achieved, that was increased up to $-31.0 \pm 18.8 \mathrm{mmHg} /-14.1 \pm 11.7$ $\mathrm{mmHg}$ with olmesartan-amlodipine $40 / 10 \mathrm{mg}$.

Patient characteristics, including age, body mass index, duration of hypertension (except for patients with a short duration in which BP lowering was enhanced) and the presence of diabetes had no substantial influence on the

Table 3 Shift table for added antihypertensive treatment at baseline and for cumulative changes at the last documented visit (safety population)

\begin{tabular}{|c|c|c|c|c|c|c|c|c|}
\hline & \multicolumn{2}{|c|}{$\begin{array}{l}\text { Olmesartan-amlodipine } \\
20 / 5 \mathrm{mg} \text { at last } \\
\text { documented visit }\end{array}$} & \multicolumn{2}{|c|}{$\begin{array}{l}\text { Olmesartan-amlodipine } \\
40 / 5 \mathrm{mg} \text { at last } \\
\text { documented visit }\end{array}$} & \multicolumn{2}{|c|}{$\begin{array}{l}\text { Olmesartan-amlodipine } \\
40 / 10 \mathrm{mg} \text { at last } \\
\text { documented visit }\end{array}$} & \multicolumn{2}{|c|}{$\begin{array}{l}\text { Total } \\
\text { (baseline)* }\end{array}$} \\
\hline & $\mathbf{n}$ & $\%$ & $\mathbf{n}$ & $\%$ & $\mathbf{n}$ & $\%$ & $\mathbf{n}$ & $\%$ \\
\hline $\begin{array}{l}\text { Olmesartan-amlodipine } \\
20 / 5 \mathrm{mg} \text { at baseline }\end{array}$ & 2877 & 37.0 & 817 & 10.5 & 301 & 3.8 & 3955 & 51.4 \\
\hline $\begin{array}{l}\text { Olmesartan-amlodipine } \\
40 / 5 \mathrm{mg} \text { at baseline }\end{array}$ & 132 & 1.7 & 1736 & 22.3 & 538 & 6.9 & 2406 & 31.0 \\
\hline $\begin{array}{l}\text { Olmesartan-amlodipine } \\
40 / 10 \mathrm{mg} \text { at baseline }\end{array}$ & 50 & 0.6 & 77 & 0.9 & 1233 & 15.8 & 1360 & 17.5 \\
\hline Total (follow-up) & 3059 & 39.4 & 2630 & 33.8 & 2072 & 26.6 & & \\
\hline
\end{tabular}

Note: *Add up to $99.9 \%$ because of rounding. 
A

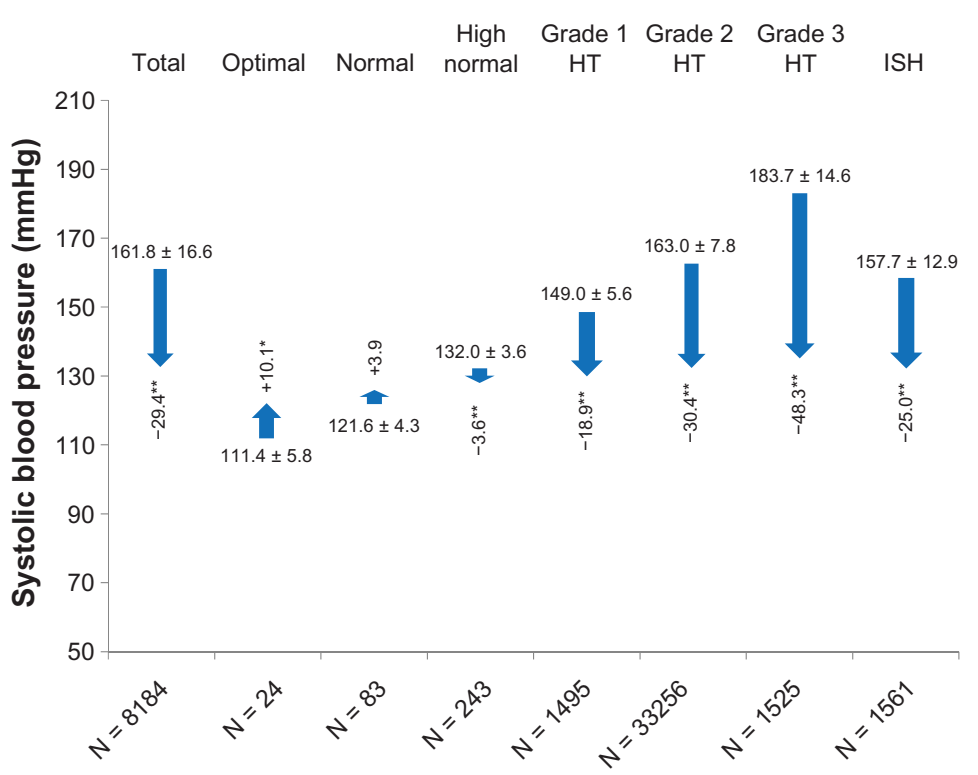

B
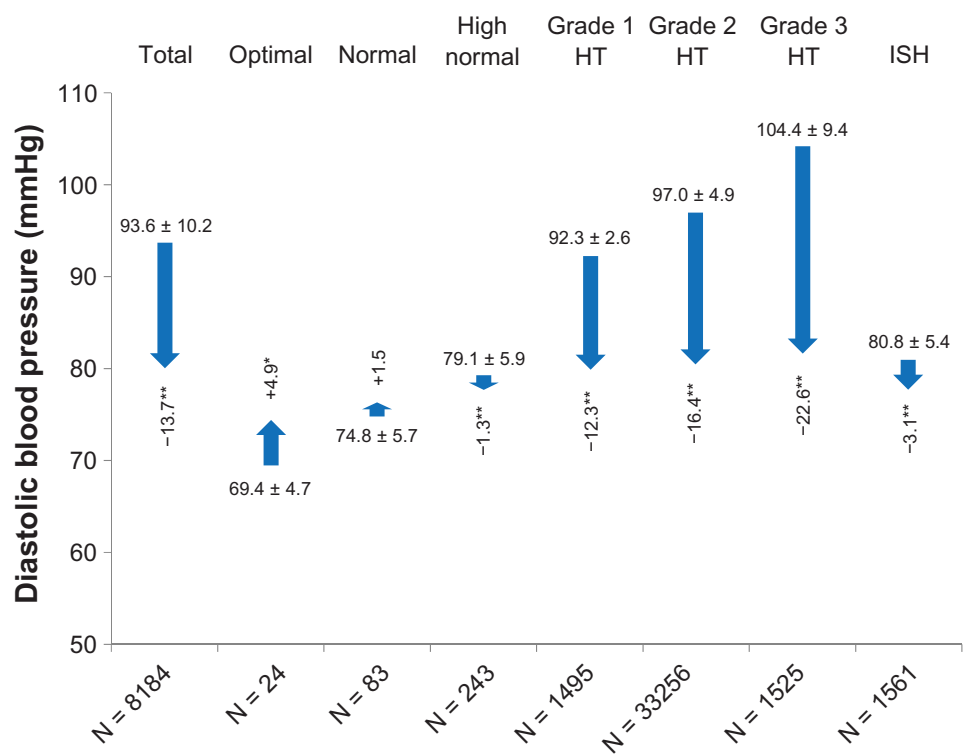

Figure 2 Blood pressure lowering with respect to blood pressure category at baseline.

Notes: $* P<0.01$; **P $<0.0001$.

Abbreviations: $\mathrm{HT}$, hypertension; ISH, isolated systolic hypertension.

Table 4 Blood pressure reduction in SERVE* and the randomized controlled trial $\mathrm{COACH}^{4}$

\begin{tabular}{|c|c|c|c|c|c|c|c|c|}
\hline & \multicolumn{4}{|c|}{$\Delta$ Systolic BP } & \multicolumn{4}{|c|}{$\Delta$ Diastolic BP } \\
\hline & SERVE & $\begin{array}{l}P \text { value } \\
\text { versus } \\
\text { baseline }\end{array}$ & $\begin{array}{l}\text { SERVE } \\
\text { subgroup** }\end{array}$ & COACH & SERVE & $\begin{array}{l}P \text { value } \\
\text { versus } \\
\text { baseline }\end{array}$ & $\begin{array}{l}\text { SERVE } \\
\text { subgroup*** }\end{array}$ & COACH \\
\hline $\mathrm{BP}$ at baseline & $161.8 \pm 16.6$ & & $166.3 \pm 15.4$ & $163.8 \pm 16.1$ & $93.6 \pm 10.2$ & & $108.0 \pm 5.9$ & $101.6 \pm 5.2$ \\
\hline $\begin{array}{l}\text { Olmesartan- } \\
\text { amlodipine } 20 / 5 \mathrm{mg}\end{array}$ & $\begin{array}{l}-27.6 \pm 16.3 \\
(n=3254)\end{array}$ & $<0.0001$ & $\begin{array}{l}-31.9 \pm 15.4 \\
(n=989)\end{array}$ & $\begin{array}{l}-23.6 \pm 14.9 \\
(n=160)\end{array}$ & $\begin{array}{l}-13.2 \pm 10.6 \\
(n=3254)\end{array}$ & $<0.0001$ & $\begin{array}{l}-19.5 \pm 8.1 \\
(\mathrm{n}=989)\end{array}$ & $\begin{array}{l}-14.0 \pm 9.1 \\
(n=160)\end{array}$ \\
\hline $\begin{array}{l}\text { Olmesartan- } \\
\text { amlodipine 40/5 mg }\end{array}$ & $\begin{array}{l}-29.5 \pm 16.5 \\
(n=2749)\end{array}$ & $<0.0001$ & $\begin{array}{l}-33.0 \pm 15.2 \\
(n=766)\end{array}$ & $\begin{array}{l}-25.4 \pm 14.7 \\
(n=157)\end{array}$ & $\begin{array}{l}-13.5 \pm 10.5 \\
(n=2749)\end{array}$ & $<0.0001$ & $\begin{array}{l}-18.8 \pm 8.1 \\
(n=766)\end{array}$ & $\begin{array}{l}-15.5 \pm 8.2 \\
(n=157)\end{array}$ \\
\hline $\begin{array}{l}\text { Olmesartan- } \\
\text { amlodipine } 40 / 10 \mathrm{mg}\end{array}$ & $\begin{array}{l}-31.0 \pm 18.8 \\
(n=2083)\end{array}$ & $<0.000$ I & $\begin{array}{l}-35.0 \pm 18.0 \\
(n=467)\end{array}$ & $\begin{array}{l}-30.1 \pm 15.9 \\
(n=161)\end{array}$ & $\begin{array}{l}-14.1 \pm 11.7 \\
(n=2083)\end{array}$ & $<0.0001$ & $\begin{array}{l}-19.8 \pm 9.7 \\
(n=467)\end{array}$ & $\begin{array}{l}-19.0 \pm 8.9 \\
(n=161)\end{array}$ \\
\hline
\end{tabular}

Note: *Assignment to dose was based on the previous visit. **SERVE patients complying with the $\mathrm{COACH}$ in- and exclusion criteria.

Abbreviation: BP, blood pressure. 
efficacy of olmesartan-amlodipine. In contrast, efficacy was nominally higher in patients without previous/concomitant antihypertensive medication than in those with prior medication $(-34.3 \pm 17.4$ versus $-28.9 \pm 16.9 \mathrm{mmHg}$ systolic and $-17.5 \pm 11.0$ versus $-13.3 \pm 10.7 \mathrm{mmHg}$ diastolic).

At the final visit (usually 12-18 weeks after enrolment), there was a strong shift in the ESH/ESC categorization (Figure 3), with $69.4 \%$ of patients (4.3\% at baseline) having only high normal BP (18.4\% isolated systolic hypertension; $19.1 \%$ at baseline). Patients with isolated systolic hypertension at the final visit usually had had moderate to severe hypertension at baseline, while patients with isolated systolic hypertension at baseline usually were categorized as being high-normal at the final visit.

\section{Tolerability}

Adverse drug reactions occurred in a total of 227 patients during the study, representing $2.76 \%$ of all included patients (Table 5). Of all adverse drug reactions, 213 were assessed as nonserious and 13 as serious by the reporting physicians. The status of seriousness was not assessable due to a lack of data in one case. Within this study, three deaths have been reported. None of them was related to the study medication according to the judgment of the treating physicians.

Table 6 shows an overview of all reported events, clustered and coded according to MedDRA (12.0; MedDRA MSSO,
Berlin, Germany). In total, 338 events were reported, the largest number (147) within the system organ class "General disorders and administration site conditions" harboring the lowest level term "peripheral edemas"; $31.5 \%$ of all reported adverse drug reactions were peripheral edema in 111/8237 patients. These results are in agreement with the physicians' assessment of tolerability which was "very good" $(70.7 \%)$ or "good" $(25.6 \%)$ in the majority of treated patients.

\section{Discussion}

There is substantial cardiovascular risk conferred by the presence of arterial hypertension, which has been shown to be reduced in patients with adequate BP control using antihypertensive medication. A fixed-dose combination of olmesartan-amlodipine, which was documented to be effective and well tolerated in previous randomized, controlled trials, ${ }^{4,7-12}$ has been observed under clinical practice conditions in the present study for a 12-18 week period resulting in the documentation of a strong BP lowering with high tolerability.

\section{Blood pressure lowering in perspective}

The results of SERVE conducted in the real-life situation include a strong reduction of BP in hypertensive patients by $29.0 \pm 17.1 / 13.5 \pm 10.9 \mathrm{mmHg}(P<0.0001$ versus baseline) with a clear correlation between $\mathrm{BP}$ at baseline and $\mathrm{BP}$

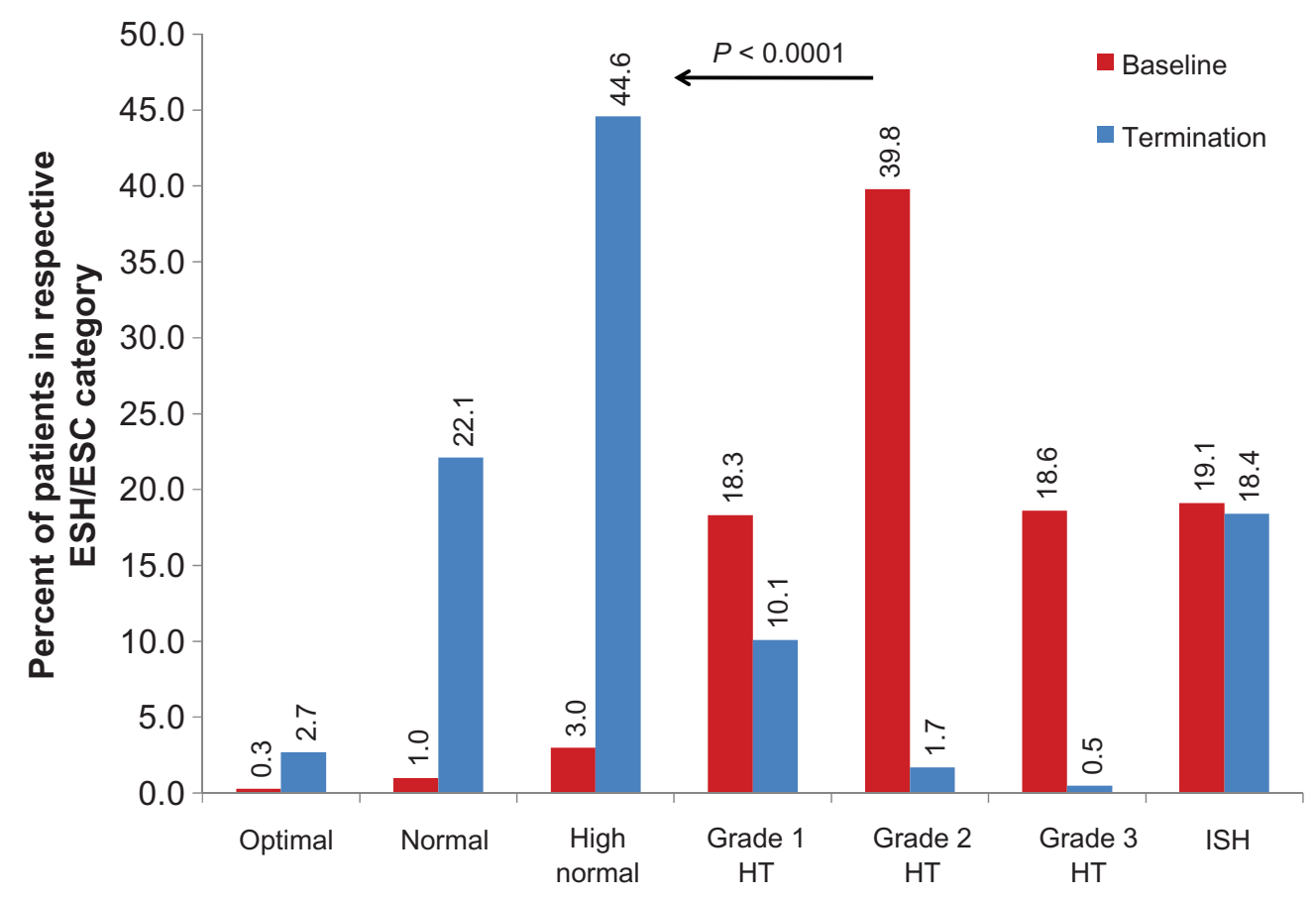

Figure 3 Blood pressure categorization according to European Society of Hypertension and European Society of Cardiology. Note: $P$ value for the comparison of classification at the termination visit versus baseline.

Abbreviations: $\mathrm{HT}$, hypertension; ISH, isolated systolic hypertension. 
Table 5 Number of patients with an adverse drug reaction in the observation period

\begin{tabular}{|c|c|c|c|c|}
\hline $\begin{array}{l}\text { Total population } \\
(n=8237)\end{array}$ & $\begin{array}{l}\text { O20, A5 } \\
\text { (patients, n) }\end{array}$ & $\begin{array}{l}\text { O40, A5 } \\
\text { (patients, n) }\end{array}$ & $\begin{array}{l}\text { O40, Al0 } \\
\text { (patients, n) }\end{array}$ & $\begin{array}{l}\text { Total } \\
\text { (patients, n) }\end{array}$ \\
\hline Patients without ADR & $4|4|$ & 2472 & 1400 & 8013 \\
\hline Patients with ADR & 91 & 54 & 79 & $226^{*}$ \\
\hline Serious & 5 & 4 & 3 & 13 \\
\hline Not serious & 86 & 50 & 76 & 213 \\
\hline Change in dose* & $\begin{array}{l}\text { O20, A5 } \\
\text { (n, \% of patients } \\
\text { with ADRs) }\end{array}$ & $\begin{array}{l}\text { O40, A5 } \\
\text { ( } n, \% \text { of patients } \\
\text { with ADRs) }\end{array}$ & $\begin{array}{l}\text { O40, Al } 0 \\
\text { ( } n, \% \text { of patients } \\
\text { with ADRs) }\end{array}$ & $\begin{array}{l}\text { Total } \\
\text { (n, \% of patients } \\
\text { with ADRs) } \\
\end{array}$ \\
\hline Not changed & $3(1.33)$ & $4(1.78)$ & $4(1.78 \%)$ & II (4.89\%) \\
\hline Drug withdrawn & $86(38.22)$ & $49(21.78)$ & $68(30.22 \%)$ & $204(90.67 \%)^{* *}$ \\
\hline Dose reduced & $\mathrm{I}(0.44)$ & I (0.44) & $6(2.67 \%)$ & $8(3.56 \%)$ \\
\hline Dose increased & I (0.44) & $0(0)$ & $0(0 \%)$ & I (0.44\%) \\
\hline Unknown & $0(0)$ & $0(0)$ & I $(0.44 \%)$ & I (0.44\%) \\
\hline
\end{tabular}

Notes: *Data from one patient not included; **One patient with unknown dose.

Abbreviation: ADRs, adverse drug reactions.

reduction (Spearman's Rho -0.811 for systolic BP and -0.759 for diastolic BP) and a dependency on dose and prior antihypertensive therapy, but not on age, gender, body mass index, duration of hypertension, or the presence of diabetes. After a usual treatment duration of $12-18$ weeks, $69.4 \%$ of patients managed to attain the high-normal BP level.

The study results at the final visit (Table 4) should be interpreted in comparison with the results of the recent randomized, controlled COACH (Counseling Older Adults to Control Hypertension) trial ${ }^{4}$ based on the respective dose level of the fixed combination. $\mathrm{COACH}$ had a follow-up of eight weeks. Mean systolic BP reductions achieved are nominally higher in SERVE than in $\mathrm{COACH}$, with differences being more pronounced in the lower dose range (olmesartanamlodipine $20 / 5 \mathrm{mg}$ ). On the other hand, the reduction of diastolic BP was stronger in COACH than in SERVE. There are a variety of reasons that might account for the observed differences in BP reduction, even beyond differences in patient characteristics outlined in Table 7. First and foremost, mean BP at baseline was 161.8/93.6 mmHg in SERVE and $163.6 / 101.5 \mathrm{mmHg}$ in $\mathrm{COACH}$, indicating similar systolic but substantial differences in diastolic BP. This would argue for a stronger reduction of diastolic $\mathrm{BP}$ in $\mathrm{COACH}$, because the fall in diastolic BP is strongly related to baseline BP. Second, the values obtained in SERVE have been obtained on the background of a variety of different drugs. The fixed

Table 6 Adverse drug reactions coded according to MedDRA ${ }^{\circledR}$ Version 12.0

\begin{tabular}{|c|c|c|c|c|}
\hline Total population $(n=8237)$ & O20, A5 & O40, A5 & O40, Alo & Total \\
\hline \multicolumn{5}{|l|}{ MedDRA $^{\circledR}$ primary system organ classes (SOC) } \\
\hline Total number of ADRs, n (\%) & $140(4 \mid .42)$ & $76(22.49)$ & $121(35.80 \%)$ & $338(100 \%)^{*}$ \\
\hline Cardiac disorders & $2(0.59)$ & $2(0.59)$ & $3(0.89 \%)$ & $7(2.07 \%)$ \\
\hline Ear and labyrinth disorders & I $(0.30)$ & I $(0.30)$ & I $(0.30 \%)$ & $3(0.89 \%)$ \\
\hline Eye disorders & $2(0.59)$ & $0(0)$ & $3(0.89 \%)$ & $5(1.48 \%)$ \\
\hline Gastrointestinal disorders & $18(5.33)$ & $12(3.55)$ & $6(1.78 \%)$ & $36(10.65 \%)$ \\
\hline General disorders and administration site conditions & $45(13.31)$ & $36(10.65)$ & $65(19.23 \%)$ & $147(43.49 \%)^{*}$ \\
\hline Hepatobiliary disorders & I $(0.30)$ & $0(0)$ & $0(0 \%)$ & $\mathrm{I}(0.30 \%)$ \\
\hline Immune system disorders & I $(0.30)$ & $0(0)$ & $0(0 \%)$ & $\mathrm{I}(0.30 \%)$ \\
\hline Infections and infestations & $0(0)$ & $0(0)$ & I $(0.30 \%)$ & $\mathrm{I}(0.30 \%)$ \\
\hline Investigations & $3(0.89)$ & $2(0.59)$ & $0(0 \%)$ & $5(1.48 \%)$ \\
\hline Metabolism and nutrition disorders & $2(0.59)$ & $0(0)$ & $0(0 \%)$ & $2(0.59 \%)$ \\
\hline Musculoskeletal and connective tissue disorders & $4(1.18)$ & $3(0.89)$ & $8(2.37 \%)$ & $15(4.44 \%)$ \\
\hline Nervous system disorders & $27(7.99)$ & $4(1.18)$ & $8(2.37 \%)$ & $39(11.54 \%)$ \\
\hline Psychiatric disorders & $3(0.89)$ & I $(0.30)$ & $9(2.66 \%)$ & $13(3.85 \%)$ \\
\hline Reproductive system and breast disorders & $2(0.59)$ & $0(0 \%)$ & $2(0.59 \%)$ & $4(1.18 \%)$ \\
\hline Respiratory, thoracic and mediastinal disorders & $8(2.37)$ & $4(1.18)$ & $2(0.59 \%)$ & $14(4.14 \%)$ \\
\hline Skin and subcutaneous tissue disorders & $13(3.85)$ & $4(1.18)$ & $7(2.07 \%)$ & $24(7.10 \%)$ \\
\hline Vascular disorders & $8(2.37)$ & $7(2.07)$ & $6(1.78 \%)$ & $21(6.21 \%)$ \\
\hline
\end{tabular}

Note: *One patient each with unknown dose. Abbreviation: ADRs, adverse drug reactions. 
Table 7 Comparison of inclusion and exclusion criteria for the SERVE and COACH studies ${ }^{4,8}$

\begin{tabular}{|c|c|c|}
\hline & $\begin{array}{l}\text { COACH } \\
\text { (Randomized, } \\
\text { controlled trial) }\end{array}$ & $\begin{array}{l}\text { SERVE } \\
\text { (Noninterventional } \\
\text { study) }\end{array}$ \\
\hline \multirow[t]{2}{*}{ Inclusion } & Men or women $\geq 18$ years & Men or women $\geq 18$ years \\
\hline & $\begin{array}{l}\text { Seated } D B P \geq 95 \mathrm{mmHg} \\
\text { and } \leq 120 \mathrm{mmHg} \\
\text { difference } \leq 10 \mathrm{mmHg} \\
\text { between } 2 \text { measurements }\end{array}$ & $\begin{array}{l}\text { Essential hypertension } \\
\text { uncontrolled }\end{array}$ \\
\hline \multirow[t]{10}{*}{ Exclusion } & $\mathrm{DBP}>120 \mathrm{mmHg}$ & \\
\hline & $\begin{array}{l}\text { History of cardiovascular } \\
\text { disease }\end{array}$ & $\begin{array}{l}\text { Cardiogenic shock, acute } \\
\text { MI ( }<4 \text { weeks), unstable } \\
\text { angina }\end{array}$ \\
\hline & Uncontrolled diabetes & $\begin{array}{l}\text { Severely reduced liver } \\
\text { function and biliary duct } \\
\text { obstruction }\end{array}$ \\
\hline & $\begin{array}{l}\text { Smoking }>\text { one pack } \\
\text { of cigarettes }\end{array}$ & \\
\hline & $\begin{array}{l}\text { Laboratory values or } \\
\text { systemic disease }\end{array}$ & \\
\hline & considered clinically & \\
\hline & significant by the & \\
\hline & investigator & \\
\hline & $\begin{array}{l}\text { Taking any medication } \\
\text { that could interfere with } \\
\text { the objectives of the study }\end{array}$ & \\
\hline & Pregnancy and nursing & $\begin{array}{l}\text { 2nd and 3rd trimester } \\
\text { of pregnancy }\end{array}$ \\
\hline
\end{tabular}

Abbreviations: DBP, diastolic blood pressure; $\mathrm{MI}$, myocardial infarction; $\mathrm{COACH}$.

combination could be added to an existing antihypertensive drug therapy and even used in treatment-naïve patients (which would not have been on-label). Third, the comparison is based on pharmacotherapy at baseline, and most of the patients were uptitrated and others were downtitrated. This also might result in a bias of the overall results towards higher BP reductions, in particularly at low doses.

While a detailed comparison of BP-lowering efficacy on a patient basis between SERVE and COACH is beyond the scope of the present analysis, the results strongly suggest that BP observed in clinical trials is similar to that found in primary care, and point to the possibility of adjusting BP effectively with the fixed-dose combination with the benefit of the known advantages of fixed-dose combinations, such as convenient use and increased patient compliance.

\section{Tolerability of fixed-dose combination}

The adverse event profile of olmesartan has been analyzed in placebo-controlled trials over two years of treatment, with more than 3000 patients showing good tolerability. ${ }^{13,14}$ On the other hand, dihydropyridine calcium channel blockers, such as amlodipine, have been associated with peripheral edema, which is likely to result from preferential arteriolar vasodilation and an increase in the pressure gradient between the arteriolar and venular capillaries, leading to exudation of interstitial fluid. ${ }^{15,16}$

Data from the recent randomized controlled $\mathrm{COACH}$ trial ${ }^{4}$ testing amlodipine up to $10 \mathrm{mg}$ and/or olmesartan up to $40 \mathrm{mg}$ versus placebo suggest an amelioration of peripheral edema with the combined use of amlodipine and olmesar$\tan$. While $36.8 \%$ of patients on $10 \mathrm{mg}$ amlodipine (18.5\% with $40 \mathrm{mg}$ olmesartan) experienced edema, the incidence was reduced to $23.5 \%$ in patients receiving a combination at the same doses. This is thought to be the result of lower precapillary resistance, normalized intracapillary pressure, and reduced fluid exudation with the use of the angiotensin receptor blocker. ${ }^{15,17}$

In this observational study, $2.76 \%$ of patients had adverse drug reactions, of which about one-third $(31.5 \%$ of the aforementioned 2.76\%) were peripheral edema, suggesting a substantially lowered risk of edema in clinical practice, or a lower vigilance of physicians in primary care for this side effect, questioning its clinical relevance. Differences in the incidence of edema may also be somewhat related to the overall treatment duration. While an incidence rate of $23.5 \%$ was reported for the first randomized, controlled eight-week phase of $\mathrm{COACH},{ }^{4}$ an incidence rate of only $14.5 \%$ was reported for the 44-week open-label extension. ${ }^{8}$ It may also be related to a certain degree of underreporting in trials such as SERVE, in which physicians were not specifically asked whether edema had been present or not, as opposed to $\mathrm{COACH}$ in which there were specific questions addressing this issue.

\section{Limitations}

The present study has the inherent limitations of noninterventional studies, including lack of a control group and no randomization. Therefore, the BP lowering reported may be a higher estimate than the true effect. On the other hand, the study documented a substantial BP reduction across a wide range of different patients, of which a proportion would not qualify for a randomized controlled trial such as $\mathrm{COACH}$, because of comorbid disease and concomitant pharmacotherapy (Table 4). Therefore, this kind of study is of particular importance when targeting a high external validity, and reflects actual clinical practice to a far greater extent than randomized trials.

\section{Conclusion}

The fixed-dose combination of olmesartan and amlodipine was effective and well tolerated in an unselected population 
of patients in primary care practice. These results confirm prior randomized controlled trial evidence.

\section{Acknowledgments}

The efforts of participating physicians, their staff, and the patients who participated in this study are acknowledged.

\section{Disclosure}

The study was funded by Daiichi Sankyo Deutschland GmbH. $\mathrm{PB}, \mathrm{RK}$, and RES received research funding and lecture honoraria from Daiichi Sankyo. WPW, TS, and WE are employees of Daiichi Sankyo Deutschland GmbH. EMF is an employee of Daiichi Sankyo Europe GmbH. The preparation of the manuscript was funded by Daiichi Sankyo Deutschland $\mathrm{GmbH}$.

\section{References}

1. Mancia G, de Backer G, Dominiczak A, et al. 2007 Guidelines for the Management of Arterial Hypertension: The Task Force for the Management of Arterial Hypertension of the European Society of Hypertension (ESH) and of the European Society of Cardiology (ESC). J Hypertens. 2007;25:1105-1187.

2. Mancia G, Laurent S, Agabiti-Rosei E, et al. Reappraisal of European guidelines on hypertension management: A European Society of Hypertension Task Force document. Blood Press. 2009;18:308-347.

3. Jamerson K, Weber MA, Bakris GL, et al. Benazepril plus amlodipine or hydrochlorothiazide for hypertension in high-risk patients. $N$ Engl $J$ Med. 2008;359:2417-2428.

4. Chrysant SG, Melino M, Karki S, Lee J, Heyrman R. The combination of olmesartan medoxomil and amlodipine besylate in controlling high blood pressure: $\mathrm{COACH}$, a randomized, double-blind, placebocontrolled, 8-week factorial efficacy and safety study. Clin Ther. 2008;30:587-604.

5. Sokol MC, McGuigan KA, Verbrugge RR, Epstein RS. Impact of medication adherence on hospitalization risk and healthcare cost. Med Care. 2005;43:521-530.
6. Mathes J, Kostev K, Gabriel A, Pirk O, Schmieder RE. Relation of the first hypertension-associated event with medication, compliance and persistence in naive hypertensive patients after initiating monotherapy. Int J Clin Pharmacol Ther. 2010;48:173-183.

7. Barrios V, Brommer P, Haag U, Calderon A, Escobar C. Olmesartan medoxomil plus amlodipine increases efficacy in patients with moderateto-severe hypertension after monotherapy: A randomized, double-blind, parallel-group, multicentre study. Clin Drug Investig. 2009;29:427-439.

8. Chrysant SG, Oparil S, Melino M, Karki S, Lee J, Heyrman R. Efficacy and safety of long-term treatment with the combination of amlodipine besylate and olmesartan medoxomil in patients with hypertension. J Clin Hypertens (Greenwich). 2009;11:475-482.

9. Mourad JJ, Le Jeune S. Effective systolic blood pressure reduction with olmesartan medoxomil/amlodipine combination therapy: Post hoc analysis of data from a randomized, double-blind, parallel-group, multicentre study. Clin Drug Investig. 2009;29:419-425.

10. Oparil S, Lee J, Karki S, Melino M. Subgroup analyses of an efficacy and safety study of concomitant administration of amlodipine besylate and olmesartan medoxomil: Evaluation by baseline hypertension stage and prior antihypertensive medication use. $J$ Cardiovasc Pharmacol. 2009;54:427-436.

11. Volpe M, Brommer P, Haag U, Miele C. Efficacy and tolerability of olmesartan medoxomil combined with amlodipine in patients with moderate to severe hypertension after amlodipine monotherapy: A randomized, double-blind, parallel-group, multicentre study. Clin Drug Investig. 2009;29:11-25.

12. Chrysant SG, Lee J, Melino M, Karki S, Heyrman R. Efficacy and tolerability of amlodipine plus olmesartan medoxomil in patients with difficult-to-treat hypertension. J Hum Hypertens. 2010 Feb 18. [Epub ahead of print].

13. Puchler K, Laeis P, Stumpe KO. Blood pressure response, but not adverse event incidence, correlates with dose of angiotensin II antagonist. J Hypertens Suppl. 2001;19:S41-S48.

14. Schindler C, Ferrario CM. Olmesartan for the treatment of arterial hypertension. Future Cardiol. 2008;4:357-372.

15. Pedrinelli R, Dell'Omo G, Mariani M. Calcium channel blockers, postural vasoconstriction and dependent oedema in essential hypertension. J Hum Hypertens. 2001;15:455-461.

16. Messerli FH. Vasodilatory edema: A common side effect of antihypertensive therapy. Am J Hypertens. 2001;14:978-979.

17. Weir MR. Incidence of pedal edema formation with dihydropyridine calcium channel blockers: Issues and practical significance. $J$ Clin Hypertens (Greenwich). 2003;5:330-335.
Vascular Health and Risk Management

\section{Publish your work in this journal}

Vascular Health and Risk Management is an international, peerreviewed journal of therapeutics and risk management, focusing on concise rapid reporting of clinical studies on the processes involved in the maintenance of vascular health; the monitoring, prevention and treatment of vascular disease and its sequelae; and the involvement of

\section{Dovepress}

metabolic disorders, particularly diabetes. This journal is indexed on PubMed Central and MedLine. The manuscript management system is completely online and includes a very quick and fair peer-review system, which is all easy to use. Visit http://www.dovepress.com/ testimonials.php to read real quotes from published authors. 